\title{
WHAT MAKES MICROFINANCE HAPPEN?
}

\author{
¿CUÁLES SON LAS CONDICIONES QUE GENERAN EL ÉXITO MICRO-FINANCIERO?
}

\section{Manuel Antonio Jiménez Castillo ${ }^{1}$}

\begin{abstract}
In this paper we have attempted to shed light on what makes development happen from those determinants that enable microfinance work as an effective tool to eradicate poverty. The effectiveness of such instrument in the generation of wealth to the poorest class demand overcoming the minimalist approach that condemns its practices to a mere provision of microfinancial services. This hypothesis will be analytically and empirically proven assuming human development as a cause and not only as an outcome of the microfinance success. To such end, two regression lines were designed where variables such as education, health and food security proved to be explanatory determinant to explain income behaviour for those beneficiaries of the microfinance programs.
\end{abstract}

Keywords: Determinants of development; human development; microcredit; poverty.

\section{Resumen}

En este trabajo nos aproximaremos al estudio de las causas del desarrollo desde aquellos elementos que hacen de la micro-financiación una herramienta efectiva en la erradicación de la pobreza. La eficacia de tal instrumento en la generación de riqueza a las clases más empobrecidas exige superar el marco minimalista de actuación que condena sus prácticas a la mera provisión de servicios microfinancieros. Esta proposición será

Doi: http://dx.doi.org/10.15359/eys.20-48.4

Fecha de recepción: 29-10-15. Fecha de reenvío: 23-11-2011. Fecha de aceptación: 23-11-15. Fecha de publicación: 08-12-15

${ }^{1} \mathrm{PhD}$ in Economics. Researcher and Professor at El Colegio de la Frontera Norte. Sede Nuevo Laredo, México. Correo electrónico: antoniojcastillo@colef.mx

Manuel Antonio Jiménez Castillo

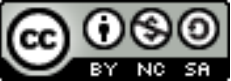

Revista Economía y Sociedad by Universidad Nacional is licensed under a Creative Commons Reconocimiento-NoComercial- 
corroborada analítica y empíricamente desde la asimilación del desarrollo humano como causa y no solo resultado del éxito microfinanciero. Para ello diseñamos dos rectas de regresión donde variables como la educación, sanidad y seguridad alimentaria mostrarán ser determinantes a la hora de explicar el comportamiento en los ingresos de los beneficiarios de tales programas microfinancieros.

Palabras claves: Determinantes del desarrollo; desarrollo humano; microcréditos; pobreza.

\section{Minimalist Approach and Microfinance}

The classical inquiry of development studies "What makes Economic Progress happen?" has been strongly discussed along the history of economic thought by a large number of scholars with disputed results (Smith, 2007; Landes, 1999; Rogers \& Stern, 2005; Acemoglu \& Robinson, 2012). Shedding light on why some countries are rich while others maintain poor is considered as one of the key point of social science. Recently, one of the methods popularized to face this issue has been microfinance, as a financial poverty's inclusion to serve in a better way humanity's most pressing needs (Yunus, 2010). Financial constrains have been highlighted as an underlying developmental barrier that holds a vast majority of developing countries' population under the absolute poverty line.

Microfinance movement began with the revolutionary idea that formal markets are unable to attract informal sector's financial demand (Yunus, 2001; Robinson, 2004). Such market failure was enough to enrich an academic literature where microfinance was placed into the core of development debate. In last three decades, it was mostly accounted that welfare in developing countries could rise up whether financial inclusion strategy were implemented, among others, in those areas where capital accumulation unveiled disarticulated. Some authors such as Karlan \& Valdivia (2011) stated that a lack of guaranties as result of badly-defined property right impede poor people reasonably access to financial program, condemning them into a vicious circle of poverty and debt. The potential high success in debt-repayment was declared as an objective fact by which the poorest could well-integrate into the financial sector as long as finance programs adapt to beneficiaries' situation (Aghion \& Morduch, 2003). To some extent this proved correct, with some Microfinance Institutions making profits without subsidies around the world. Nevertheless, the matter was highly focused on a restrictive interpretation, confusing poverty decline with financial sustainability (Jimenez, 2013).

This new kind of social business developed by M. Yunus among others, has recently received some strong criticizes in terms of its real capability to explain the struggle of poverty across the

2

Manuel Antonio Jiménez Castillo

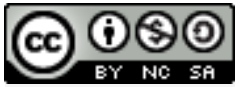

Revista Economía y Sociedad by Universidad Nacional is licensed under a Creative Commons Reconocimiento-NoComercial- 
developing world (Baneriee \& Duflo, 2011). The minimalist approach defined as the mere provision of financial resources to poor people, has been insufficiently proved to enhance their standards of living. The intellectual struggle among pro-minimalist and pro-integrated approach has driven microfinance and poverty reduction debate in an infertile and irresolvable understanding (De la Cruz et al., 2009; Cohen \& Nelson, 2011). In this paper, we account to review the epistemological bases in which microfinance is traditionally settled. To this end, we contrast the predictable potentiality of minimalist approach from a reinterpretation of its conceptual framework. Our primary goal is to reflect on the theoretical question regarding to "why there is a strong controversial related to microcredit impact on fostering human development" (Nanor, 2008; Karlan \& Zinman, 2009; Devoto et al. 2011). Also, we will expose the specific limitations of minimalist approach and its integrated alternative, introducing a new re-conceptualization of microfinance as a non-aprioristic developmental phenomenon. In this sense, we propose a different microfinance scenario, analyzed as result of the economic and social system in which it gets involved. Finally, we design an econometric regression in order to corroborate this issue. Taken three distinctive human variables such as Education, Health and Food Security, we hypothesize a correlation between those independent variables and microcredit impact on micro-borrowers standard of living.

The aim of this paper is not fully theory-oriented, but also motivated by the gap between the classical minimalist and integrated approaches and the empirical reality. In most works related to minimalist theory (Robinson, 2004;Yunus, 2010) a surprisingly uniform answer defines microcredit as a suitable instrument for stimulating profitable investment when the empirical evidence tends to suggest a different story. Over 50 studies of microcredit impact assessment, Khandeker (1998) showed that the impact on poverty reduction and food security across developing countries is insignificant, and the Poverty Action Lab, after nearly 300 studies implemented, showed a slightly positive effect on reaching Millennium Development Goals. Similarly, the alternative approach was tested equally unable to increase microfinance efficiency. Despite some positive outcomes listed by Cohen \& Nelson (2011) and Leatherman \& Dunford (2011), where microfinance effectiveness increase when it is pooled with others no financial services, a substantial number of studies have not appreciated significant results (Fisher\&Sriram, 2002), (Karlan\&Zinman, 2009). Our model offers a suggestive explanation of why neither of those microfinance approaches work efficiently as aprioristic, designing new theoretical and econometric interpretation of microfinance as result of other phenomena.

In our study, it is found that microfinance effective operability (financial sustainability and social purposes) do not derive from its self-potential features, but the social and human condition where microfinance program is implemented. It is not only a social supporting as integrated approach defends (De la Cruz et al., 2009), but a new manner of (Meta)-analysing microfinance from developmental experience. We show that when microfinance services fail to reduce poverty, it is because programs have not been implemented taking into account how human

Manuel Antonio Jiménez Castillo

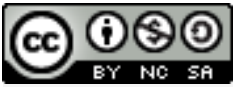

Revista Economía y Sociedad by Universidad Nacional is licensed under a Creative Commons Reconocimiento-NoComercial- 
development variables radically affect those aspect that determinate microfinance success. Such way of analysing microfinance strongly assumes human development as essential part of microfinance social targets. In a first sight, this argument might appear to be ambiguous since microfinance is focused as "object under analysis" rather than being a direct instrument for development. Nevertheless, it is exactly in such meta-philosophy of assuming microfinance as an instrument to be explored where this work gains its relevance.

This paper provides a theoretical support for a new understanding of economic development. Analysing microfinance throughout this methodology supposes explaining development from a new multidisciplinary approach rather than fixing economic phenomena to a simplistic and mechanical classical interpretation. The rest is organized as follow. Section 2 discusses the related literature. Section 3 presents the new theoretical microfinance approach considered as an "epistemological bridge" from minimalist and integrated microfinance approach to a new manner of conceiving microfinance. Section 4 presents an econometric model, which justifies the theoretical assumptions evolved in preceding section, and Section 5 presents the results. Section 6 concludes.

\section{Microcredits and Human Development}

The specific literature related to ex-post microfinance approach is clearly limited. Analysing microfinance as consequence of others phenomena has not been largely considered by academic due to the dominance of classical epistemological framework that for so long has monopolized development economic research.

Microfinance literature has been traditionally distinguished by two different models of lending. On one hand, microcredit lending with joint liability that Aghion \& Murdoch (2003) has strongly defended as a suitable strategy to assure repayment through peer pressure in microcredit schemes. Others such as Devoto et al. (2011) argue that this kind of lending may also reinforce social activities, reducing monitoring and information costs. Besley \& Coate's (1993) and Ghatak \& Guinnance's (1999) research defend joint responsibility as the optimal system to reduce verification costs and moral hazard problems using a "frequent repayment" system. Precisely, it is here where our paper gains its originality, since both sets of works account only one side of the equation. For example, some researchers such as Mcintosh \& Wydick (2002) and Field \& Pande (2007) have severely disputed the group-lending's potential benefits. The difficulty to create optimal size of groups lending and the increasing cost to generate social capital among groups (Sadoulet, 2003) tend to diminish potential benefits. On the other hand, it has recently raised individual liability as alternative method to overcome some joint liability barriers. Throughout a progressive lending and for an empirical research implemented in Filipinas, Yunus (2001) and Giné \& Karlan (2007) concluded that this individual mechanism control is not only a more cost-efficient, but return rate-effective.

4

Manuel Antonio Jiménez Castillo

$$
\text { (c) (i) } 8 \text { (O) }
$$

Revista Economía y Sociedad by Universidad Nacional is licensed under a Creative Commons Reconocimiento-NoComercial- 
Our paper is clearly far related to all of those empirical works unable to prove significant impact on poverty reduction and income distribution (Khandker, 1998, Montgomery, 2005, Nanor, 2008, Karlan \& Zinman, 2009). Even those that propose an integrated approach as De la Cruz's et al. (2009) and Nelson's (2011) studies are also distant from our aim. Some integrated research studies such as Karlan \& Valdivia (2011) in which they incorporated financial advice to increase the potential effects of micro-lending on employment and female empowerment, have not shown significant correlation. In any case, this particular approach is underlying to start designing our new epistemological basis due to it inserts in an insufficient but underlying way human variable into microfinance context.

\section{Searching for a New Theoretical Approach}

Despite minimalist microfinance approach has particularly spread the understandable spheres of economic development; it is not enough to postulate it as a well-defined instrument for enhancing human development and reducing poverty. Along with the so-called "integrated approach", they are commonly featured for being expressed in deterministic and inconsistent terms, reducing the large sort of development dynamics to a fetishized interpretation of its framework. From this perspective, it raises a simplified dialectical relationship among microfinance and development; strongly restricting it to an impoverished hermeneutics. The fact of "getting better" of integrated approach is subordinated to a minimalist framework and not to the empirical evidence ( $\underline{\text { imenez, 2013 }}$ ). In this sense, all types of human variables inserted in this approach such as financial education, health and food security are condemned to a reductionism sphere constrained to microfinance minimalist framework.

As we have already exposed, we attempted to explain microfinance as consequence of human phenomena from a multidisciplinary approach. For that reason, we focused our research on a complexity reality through a development epistemological turning. Through this shift, this paper presents development as a non-deterministic dynamics caused by a sort of interrelation elements that successfully shape it. For all of these, we econometrically present microfinance as result of some others specific human phenomena.

\section{Model Setting}

\section{Preliminaries}

It is rarely to find out along microfinance literature an empirical conclusion where microcredit is presented simultaneously as primary cause and empirical consequence of other developmental phenomena. In this paper, we measured the determination of human variables on microcredit impact as income-maker and poverty reduction instrument.

Manuel Antonio Jiménez Castillo

$$
\text { (c) (P) (9) }
$$

Revista Economía y Sociedad by Universidad Nacional is licensed under a Creative Commons Reconocimiento-NoComercial- 
For implementing this unprecedented empirical research we made use of an econometric model composed by 4 variables where 3 of them (Education, Health and Food Security) were explanatory or independent human variables, whereas dependent one was defined as the impact of microcredit on individual incomes.

In order to contrast whether human development is a crucial factor to explain microcredit impact, we disaggregated microcredit variable in a double direction that allowed to design two econometric regressions by a sample of 28 and 18 countries respectively, where microfinance program was implemented: on one hand, and for the first regression, the impact of microcredit was addressed by all individual incomes of microcredit programs implemented for a sample of 28 impact assessments; for the second regression, and for expressing the impact on poverty reduction, microcredit variable was composed only by those 18 sample-data in which microcredit impact on income was clearly higher. While for the first regression we are concern about in what grade microfinance operability is explained by human development; in the second one, we focus on how human development determinates microfinance as a poverty decline instrument. In this sense, we have assumed with the large restriction of the data available that poverty decline will be correlated with those microfinance programs (18) which underwent the largest impact on micro-borrowers incomes. Even whether such reasoning has many analytical weaknesses can be useful in order to explain in what grade human development is a key factor for microfinance success in terms of poverty decline and not only as financial repayment activity. Finally, we justified independent variables elected by potential effects on human development ${ }^{2}$.

\section{Experimental design}

For dealing with the empirical design, we have selected an econometric approach following the least squares method. Such model was explained by a regression line whose function is given by $Y=f(X \imath, X 2, \ldots, X \kappa ; \beta)$; where $\mathrm{Y}$ is a dependent variable and $X l, X 2, \ldots X \kappa$ are independentones. Since the purpose of this research rested on the identification of microcredit impact determinants, a double lineal regression line was designed;

$$
\begin{aligned}
& Y=\beta_{0}+\beta_{1} E+\beta_{2} H+\beta_{3} F S+\omega \\
& Y^{*}=\beta_{0}+\beta_{1} E^{*}+\beta_{2} H^{*}+\beta_{3} F S^{*}+\omega^{*}
\end{aligned}
$$

\footnotetext{
${ }^{2}$ See Gallup \& Sachs, 2001; Leive \& Xu, 2008; Banerjee \& Duflo, 2011)
}

6 
For the design of each variable, we collected a set of indicators from the World Bank's and UNDP's database that derived from the impact assessment sample used for the analysis ${ }^{3}$. Such indicators for Education variable were: youth literacy, population reaching grade 5 and primary enrolment. For Health variable were selected the following: infant immunized, maternal mortality, and safe drinking water. Finally, for Food Security variable was composed by national consumption, infant with low birth weight and infant mortality. The purpose for selecting such variables is twofold. On one hand, all such indicators are highly explicative of each variable indicated; in the sense of reflecting the most underlying aspect of its meaning as traditionally follow United Nations. On the other hand, the restrictions of indicators derive from the scarcity of some data and the undermined capability to data-collection in some poor countries.

Subsequently, indicators data obtained directly from the World Bank and United Nations Development Program were homogenized in a same measuring unit throughout the composition of a sort of indices that follow the Human Development Index (UNDP, 1994). For each indicator a limited value derived from a maximum and minimum was established by a general formulation. Even if for the design of indexes we assume the HDI methodology, some of them was necessary redesigned following some variations from the original formulation in order to standardize the data. For example, to obtain the index "infant mortality" we designed a logarithmic function to avoid some imbalance in the data produced by using as maximum and minimum ratio extreme values from 0 to 100.000. Since index values range between 0 and 1 , and considering 1 as the best possible result, those countries where infant mortality rate is lower would be corresponded with an index close to 1 . Therefore, the index for infant mortality can be expressed by following

$$
\text { Infant M.I. Corrected }=1-\frac{\log (\text { real val. })-\text { min. val. }}{\log (\text { max.val. })-\text { min.val. }}
$$

To obtain such indexes that comprise food security variable have been conducted the following modifications derived from the general formulation. For the equation (2) "national consumption of the poorest quintile" has made used of the logarithmic version in base 10 to compensate the disruption that causes a range between the minimum and the maximum value comparatively smaller than other indexes.

$$
\text { NationalConsumption }=\frac{\log (\text { real val. })-\min . \text { val. }}{\log (\max . v a l .)-\min . \text { val. }}
$$

\footnotetext{
${ }^{3}$ We used a sample of 28 evaluations of microcredit's impact on incomes. According to those countries where each evaluation was implemented, we collected their statistic data in terms of education, health and food security, in accordance with those indicators that composed each independent variable. Source: http://data.worldbank.org/ and http://hdr.undp.org/en/data
}

Manuel Antonio Jiménez Castillo

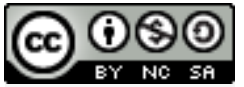

Revista Economía y Sociedad by Universidad Nacional is licensed under a Creative Commons Reconocimiento-NoComercial- 
In order to design the index (3) 'rate of babies with low birth weight" and since a low rate would correspond to a high level, we have corrected the relationship using the following arithmetic formulation:

$$
\text { Infant with low weight Corrected }=1-\frac{\text { real val.-min.value }}{\text { max. val.-min. val. }}
$$

Finally, for the equation (4) we followed the same arithmetic logic as the education index "maternity mortality".

$$
\text { Maternal M .I. Corrected }=1-\frac{\log (\text { real val. })-\text { min. val. }}{\log (\max . \text { val. })-\min . \text { val. }}
$$

After indexes estimation process, each variable was arithmetically designed according to its human significance ${ }^{4}$. For the case of Education variable (5), the fact of weight in a higher proportion youth literacy index derives from its much more qualitative relevance in order to explain the real meaning of education (PNUD, 2012). This is the only index that considers the implications of education in the real life of young people.

$$
\text { Education }=\frac{2}{5} \text { youthliteracy }+\frac{2}{5} \text { pop.reaching } 5 \underline{0}+\frac{1}{5} \text { primaryenroll }
$$

Secondly, for Health variable (6) we have weighted in a higher proportion infant immunized index since it reflects in a considerable manner some kinds of distributional health services among population. In the next table, we expose the results obtained after the data transformation.

$$
\text { Health }=\frac{2}{4} \text { infantimmu. }+\frac{1}{4} \text { maternalmort. }+\frac{1}{4} \text { safedrinkingwater }
$$

Finally, Food Security variable equation (7) is weighted accounting the capacity of each index for reflecting the well-provision of familiar, cultural and economic assets. Although national consumption shows some particular aspects of income distribution, it is more "static" in comparison to the others, in the sense of being substantially impermeable to reflect some indirect social implications. The results are presented in the following table.

\footnotetext{
${ }^{4}$ The manner in which indexes were weighted does not respond to any statistical treatment but the literature review's understanding on human development. For this empirical approaching, we assumed that the special nature of such indexes cannot be statistically homogenized without losing some of its problematic meaning. For such reason, indexes were treated in accordance with what development theory states about the relationship between such indexes and variables.
}

8

Manuel Antonio Jiménez Castillo

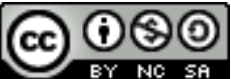

Revista Economía y Sociedad by Universidad Nacional is licensed under a Creative Commons Reconocimiento-NoComercial- 


$$
\text { FoodSecurity }=\frac{1}{5} \text { nationalconsum. }+\frac{2}{5} \text { infan.lowb. } w+\frac{2}{5} \text { infan. mortal }{ }^{5}
$$

To design dependent variable we followed a double methodological phase. Firstly, we converted indicator of microcredit impact on individual income to current US\$ for each microcredit program.

$$
\text { Indiv. Incomes } \$(\text { Baseyear })=\text { Ind.IncomesImpac. } \times X E(P P P)
$$

After that, indicators were statistically treated and converted in constant US\$. Thus, the arithmetical equation that express microcredit variable can be represented by this manner;

$$
\text { Microcredit impact } \$(2011)=\text { Microcredit imp. } \$+\frac{\text { cum.inflation } x \text { Microcreditimp. } \$}{100}
$$

Finally, all data were processed usingEviews' econometric program, getting the following results exposed in the next section.

\section{Microcredit and its potential Human Determinants}

\section{Effects of Human Development on Microcredit Impact}

The correlation results for the regression 1 between microcredit impact on individual income and human variables are strongly positive. According to the data, we state that microfinance operability (financial sustainability) demands as key factor high levels of human development to make it works. The analysis of determination coefficient indicated that human development variables explain microcredit impact in $88,5 \%$. That means that the level of explained variability in the model is quite high and robust.

In terms of coefficient estimation, we observed that average value of microcredit impact is strongly determined by independent variables. As it can be observed from Table 1, Health coefficient reached the highest value with 156,9 followed by Food Security with 146,3 and Education with 108,9. These results show that human development variables not only explain in a strongly way microcredit impact's statistical behaviour but they also strongly determinate it.

\footnotetext{
5 Infant mortality rate can be interpreted from a multidimensional perspective. Even if it is often seen as an indicator of a population's health status, it can be also associated with the national capacity to ensure food resources in order to avoid famines, droughts and other natural disasters. Taking into account that many of infant deaths derive from undernourishment (UNDP, 2012), such index can be suitable interpreted to mean food security variable.
}

Manuel Antonio Jiménez Castillo

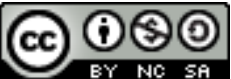

Revista Economía y Sociedad by Universidad Nacional is licensed under a Creative Commons Reconocimiento-NoComercial- 


\section{Effects of Human Development on Microcredit as Poverty Reduction Instrument}

In reference to the second hypothesis, we analysed statistically the relationship between human development variables and microcredit impact on poverty reduction. As it was mentioned earlier, we assume poverty decline effects in those 18 microfinance programs where microborrowers incomes were higher. The idea was to conceptualize both the role of human development in the sustainability of microfinance programs and its capability to makes microfinance an instrument for development. In this sense, the philosophy behind this is not longer than releasing the role of human development as cause and not only results of microfinance success. What does the data show? The coefficient of determination indicates that human development variables explain microcredit impact in $88 \%$. Whether we compare with regression 1 , that means that statistic determination of human variables has almost the same relevance on microcredit impact.

Regarding coefficients outcomes, the model result that Food Security is the most significant variable $(187,58)$ followed by Health $(123,55)$ and Education $(91,18)$. Whether we compare coefficient results for both regressions, we obtained that Education is significantly less determinant than the others variables. Similarly, outcomes reflect that Food Security is the most relevant variable when we considered microcredit as an instrument for poverty-reduction while Health rises to the top for explaining the impact on individual incomes. We could also indicate that Food Security, Health and Education variables are clearly less significant to explain microcredit as poverty reduction instrument than as income-making. Such results could be interpreted following evidence generated by Arcand \&Faye (2002). They expose that stability and free access on food provision could definitively reduce economic uncertainty, realising economic resources to other financial purposes.

\section{Primary Results}

The findings of this study are consistent with the epistemological turningon microcredit approach hypothesized along this paper. Although there are not specific studies that emphasize microcredit as result of others phenomena, our empirical study reinforce the complexity idea according to which what makes microcredit work depends not entirely on microcredit policies design but strongly on the grade of human development. Taken all these findings we suggest that even though an optimal design of microcredit programs is required for an efficient implementation, external conditions such as Education, Health and Food Security are in a great proportion determinant of its successfulness.

The findings on Education show that its statistical significance is absolutely lower than those other human variables. These results are clearly inconsistent with those of Bruhn \& Love (2009), where Education is considered as the strongest variable in strengthening financial inclusion. In

10

Manuel Antonio Jiménez Castillo

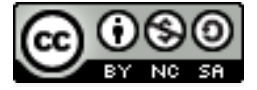

Revista Economía y Sociedad by Universidad Nacional is licensed under a Creative Commons Reconocimiento-NoComercial- 
this sense, this study also contradicts the claim robustly defended by Todd (1996) who presents education literacy as the secret element for enhancing microcredit repayment in joint liability lending models. Nevertheless, the implications of our paper do not finish here. Even referring to Education and whether, we connect our empirical results with those of Karlan \& Valdivia (2011), we may conclude that education could not be the most relevant factor to increase microcredit investment on micro-business. The thesis holds by MkNelly \& Dunford (1998) indicates that education and financial literacy are the most relevant variables to increase micro-investment and thus, marginal returns in those micro-enterprises aimed to enhance the rate of employment.

The results on Food Security, revealed as the most significance human variable in order to explain microcredit success, contributed to shed light on Banerjee \& Duflo's (2011) findings. According to this research, those micro-borrowers who received a microcredit for specifically entrepreneur purposes just only invested a slight proportion on it. That arises from low expectative of future economic returns and high uncertainly that force to invest a considerable amount of microcredit to basic goods (Maniruzzama \& Rutherford, 1998). In this sense, our results are consistent with this theory due to when food consumption is guaranteed microborrowers release more financial resources to entrepreneurial activities. In general, we could maintain that uncertainty reduction is the most relevant factor to increase microcredit effectiveness. As our results point out, health and food security are revealed as priority elements to explain microcredit. While Education holds as pertinent factor of microcredit significance, its relevance as Nelson (2011) argues, depends on a previous mitigation of high social and economic uncertainly.

\section{Conclusions}

In the vast majority of microcredit programs implemented across developing countries over the last decade, the effects on poverty reduction and human rights increasing have traditionally been so poor (Banerjee \& Duflo, 2011). It is important to comprehend how could become microcredit in a better development instrument to increase poorest people's standard of living. In particular, the results of our study provide some fascinating insights in order to make better understandable the mechanism that allow microcredit increases its economic potentiality for diminishing economic misery. For doing that, we presented an epistemological turning -from minimalist to complexity approach- where external conditions (human and social development) were addressed as determinant of microcredit impact. Contrary to what classical literature predicts, microfinance is clearly unable to impact on economic poverty without considering its effects as part of a wider scenario where human development works as potential promoter. Our meta-model predicts that human development variables strongly affect microcredit operability as development instrument. We also obtained, what really impede microfinance prodevelopmental effects are not a political design of repayment responsibility but rather a reduction of material and health uncertainly as our model clearly express.

Manuel Antonio Jiménez Castillo

(c) (i) $\$$ (O)

Revista Economía y Sociedad by Universidad Nacional is licensed under a Creative Commons Reconocimiento-NoComercial- 
Thus, this study has attempted to refocus how development in general and microfinance in particular should be analysed. Our results predict that developmental success by microfinance programs is strongly associated with human development matters. To sum up, in a complexity approach, human development is not only consequence but rather cause of a developed economy.

\section{References}

Acemoglu, D., \& Robinson, J. (2012). Why Nations Fail. The Origins of Power, Prosperity and Poverty. Retrieved from https://books.google.co.cr/books?id=ylV NMDDIvYC\&redir esc=y

Aghion, B., \& Morduch, J. (2003). The Economics of Microfinance. Cambridge: the MIT Press.

Arcand, J. \& Faye, I. (2002). Health and Economic Growth: Findings and Policy Implications. Retrieved from http://www.upf.edu/pdi/cres/lopez casasnovas/ pdf/health economic.pdf

Banerjee, A., Vinayak, A., \& Duflo, E. (2011). Poor Economics: A Radical Rethinking of the Way to Fight Global Poverty. Retrieved from https://books.google.co.cr/books?id=TjOTFOIHlyAC\&redir esc=y

Besley, T. \& Coate, S. (1993). The Economics of rotating savings and credit associations.American Economic Review, 3(83), 792-810.

Bruhn, E., \& Love, I. (2009). The Economic Impact of Banking the Unbanked.Evidence from Mexico.http://dx.doi.org/10.1596/1813-9450-4981

Cohen, M. \& Nelson, C. (2011). Financial literacy: A step for clients towards financial inclusion (Commissioned Workshop Paper). Retrieved from http://citeseerx.ist.psu.edu/viewdoc/download?doi=10.1.1.466.2029\&rep=rep1\&type= pdf

De la Cruz, N., Crookston, B., Gray, B., Alder,S., \&Dearden, K. (2009). Microfinance against malaria: impact of Freedom from Hunger's malaria education when delivered by rural banks in Ghana. Transactions of the Royal Society of Tropical Medicine and Hygiene, 103(12), 1229-1236. http://dx.doi.org/10.1016/j.trstmh.2009.03.018

12 
Devoto, F., Duflo, E., Dupas, V., \& Pouliquen, V. (2011). Turning a Shove into a Nudge? A Labeled Cash Transfer for Education (Working Paper No.19227) Retrieved from web site of The National Bureau of Economic Research: http://www.nber.org/papers/w19227

Field, E. \& Pande, R., (2007). Repayment Frequency and Default in Micro-Finance: Evidence from India.

Retrieved

from

http://www.hks.harvard.edu/fs/rpande/papers/repayfreqjeea 1107.pdf

Fisher, T. \& Sriram, M., (2002). Beyond micro-credit: Putting development back into microfinance.

Retrieved

from https://books.google.co.cr/books/about/Beyond_Micro_credit.html?id=jfBnBtxmPUwC \&redir esc $=y$

Gallup, J. \& Sachs, J. (2001). The Intolerable Burden of Malaria: A new look at the numbers. The American Journal of Tropical Medicine and Hygiene, 64(1). Retrieved fromhttp://www.ncbi.nlm.nih.gov/books/NBK2624/

Ghatak, M. \& Guinnance, T. (1999). The Economics of lending with joint-liability: theory and practice. Journal of Development Economics, 60(1), 195-228. http://dx.doi.org/10.1016/S0304-3878(99)00041-3

Giné, X. \& Karlan, D. (2007). Group versus Individual Liability: A Field Experiment in the Philippines. Retrieved from http://wwwwds.worldbank.org/external/default/WDSContentServer/WDSP/IB/2006/09/18/00011 2742 20060918174212/Rendered/PDF/WPS40081IE70B3111130ADDITIONALOCOTITL. pdf

Jimenez, A. (2013). Economía del desarrollo humano y microfinanciacion. Una aproximación a los determinantes del Microcrédito. (Tesis doctoral inédita, Universidad de Sevilla).Retrievedfromhttp://fondosdigitales.us.es/tesis/tesis/2078/economia-deldesarrollo-humano-y-microfinanciacion-una-aproximacion-los-determinantes-demicrocredito/

Karlan, D., \& Zinman, J. (2009). Expanding Microenterprise Credit Access: Randomized supply decisions to estimate impacts in Manila (Economic Department Working Paper, №68). Yale University. Retrieved from web site Department of Economics Yale University: http://economics.yale.edu/sites/default/files/files/WorkingPapers/wp000/ddp0068.pdf 
Karlan, D., \& Valdivia, M. (2011). Teaching Entrepreneurship: Impact of Business Training on Microfinance Clients and Institutions. The Review of Economics and Statitics, 93(2), 510527.http://dx.doi.org/10.1162/REST a 00074

Khandker, S. (1998). Does Microfinance really benefit the poor? Evidence from Bangladesh, paper delivered at Asia and Pacific Forum on Poverty: Reforming policies and institutions for poverty reduction. Held by the Asian Development Bank. Retrieved from http://pdf.wri.org/ref/morduch_02_analysis_effects.pdf

Landes, D. (1999). The Wealth and Poverty of Nations. Why are some so rich and some so poor. Retrieved from https://books.google.co.cr/books/about/The_Wealth_and_Poverty_of_Nations Why So.html?id=A6JPn5zAR1AC\&redir esc=y

Leatherman, S., Dunford, C.,Metcalf, M.,\&Reinsch, M.(2011).Integrating Microfinance and Health.Benefits, Challenges and Reflections for moving forward. Retrieved from http://www.microcreditsummit.org/resource/38/integrating-microfinance-and-healthbenefits.html

Leive, A. \& Xu, K. (2008). Coping with Out-of-Pocket Health Payments: Empirical Evidence from 15 African Countries.Bulletin of the World Health Organization, 86(11), 849-56. Retrieved from http://www.who.int/bulletin/volumes/86/11/07-049403.pdf

Maniruzzama, M. \& Rutherford, S. (1998). Exploring Client Preferences in Microfinance.The Consultative Group to Assist the Poorest.

Mclntosh, C. \& Wydick, B. (2002). Competition and Microfinance.Working Paper, Berkeley, University of San Francisco.Retrieved form http://repository.usfca.edu/cgi/viewcontent.cgi?article=1019\&context=econ

MkNelly, B., \&Dunford, C. (1998). Impact of credit with education on mothers and their Young children's Nutrition: Lower Rural Bank Credit with Education Program in Ghana. (Research Paper No.4). Retrieved from web site Freedom from Hunger: https://www.freedomfromhunger.org/impact-credit-education-mothers-and-theiryoung-children\%E2\%80\%99s-nutrition-lower-pra-rural-bank

Montgomery, H. (2005). Serving the Poorest of the poor: The poverty impact of the Khushhali Bank's Microfinance Lending in Pakistan. Retrieved fromhttp://www.adb.org/publications/serving-poorest-poor-poverty-impact-khushhalibanks-microfinance-lending-pakistan

14

Manuel Antonio Jiménez Castillo

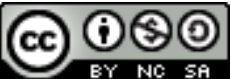

Revista Economía y Sociedad by Universidad Nacional is licensed under a Creative Commons Reconocimiento-NoComercial- 
Nanor, M. (2008). Microfinance and its impact on selected districts in Eastern Region of Ghana.Final Dissertation. Retrieved fromhttp://ir.knust.edu.gh/handle/123456789/598

Nelson, L. (2011). From Loans to Labour: Access to Credit, Entrepreneurship and Child Labour. Mimeo.

Retrieved

from http://www.colorado.edu/Economics/seminars/SeminarArchive/2011-12/Nelson.pdf

United Nations Development Programme (1994). Human Development Report 1994.Retrieved fromhttp://hdr.undp.org/en/content/human-development-report-1994

United Nations Development Program (2012). Concept and measurement of Human Development 2012. Retrieved from http://hdr.undp.org/en/reports/global/2000?page=1

Robinson, M. (2004). La Revolución Microfinanciera. Finanzas sostenibles para los pobres. Retrieved fromhttp://wwwwds.worldbank.org/external/default/WDSContentServer/WDSP/IB/2007/05/11/00002 0953 20070511133803/Rendered/PDF/232500v10SPANI1180015721X001PUBLIC1.pdf

Rogers, H., \& Stern, N. (2005). Growth and Empowerment: Making Development Happen. Retrievedfromhttps://mitpress.mit.edu/books/growth-and-empowerment

Sadoulet, L. (2003). The role of mutual insurance in group lending.Draft, ECARES, Free University.Retrived from http://www.researchgate.net/publication/247985788 The Role of Mutual Insurance in Group Lending

Smith, A. (2007). An Inquiry into the Nature and Causes of the Wealth of Nations. Retrieved from http://www.ibiblio.org/ml/libri/s/SmithA WealthNations_p.pdf

Todd, H. (1996). Women at the center: Grammer Bank borrowers after one decade. Retrieved from http://uplbooks.com.bd/book/women-center-grameen-bank-borrowers-afterone-decade

Yunus, M. (2001). Banker of the Poor: The Autobiography of Muhammad Yunnus, Founder of the Grammer Bank. Retrieved from http://www.amazon.com/Banker-Poor-AutobiographyMuhammad-Founder/dp/0195795377

Yunus, M. (2010). Building Social Business. The New Kind of Capitalism that serve humanity's most pressing needs. Retrieved from https://books.google.co.cr/books?id=WOEDHD28NB8C\&redir_esc=y 


\section{Appendixes}

Table 1.

Education Outcomes

\begin{tabular}{|c|c|c|c|c|c|c|c|}
\hline \multirow{3}{*}{ Countries } & \multicolumn{6}{|c|}{ Indicators \indexs } & \multirow{3}{*}{ Variable } \\
\hline & \multicolumn{2}{|c|}{ Youth literacy } & \multicolumn{2}{|c|}{$\begin{array}{c}\text { Population reaching } \\
\text { grade } 5 \\
\end{array}$} & \multicolumn{2}{|c|}{ Primary enrolment } & \\
\hline & $\begin{array}{c}\text { Indicator } \\
(\%)^{*}\end{array}$ & Index & $\begin{array}{l}\text { Indicator } \\
(\%)^{* *}\end{array}$ & Index & $\begin{array}{c}\text { Indicator } \\
(\%)^{* * *}\end{array}$ & Index & \\
\hline Bangladesh & 63,00 & 0,330 & 54,00 & 0,540 & 33,00 & 0,630 & 0,450 \\
\hline Bangladesh $^{*}$ & 75,10 & 0,377 & 67,00 & 0,670 & 37,70 & 0,751 & 0,536 \\
\hline Bangladesh $^{* *}$ & 87,00 & 0,497 & 65,00 & 0,650 & 49,70 & 0,870 & 0,610 \\
\hline Bolivia & 94,30 & 0,973 & 78,00 & 0,780 & 97,30 & 0,943 & 0,903 \\
\hline Brazil & 97,10 & 0,920 & 71,00 & 0,710 & 92,00 & 0,971 & 0,858 \\
\hline Chile & 90,40 & 0,987 & 99,90 & 0,999 & 98,70 & 0,904 & 0,977 \\
\hline Ethiopia & 35,20 & 0,345 & 51,00 & 0,510 & 34,50 & 0,352 & 0,401 \\
\hline Filipinas & 94,00 & 0,951 & 75,00 & 0,750 & 95,10 & 0,940 & 0,882 \\
\hline Ghana & 43,40 & 0,895 & 63,00 & 0,630 & 89,50 & 0,434 & 0,729 \\
\hline Haiti & 19,40 & 0,441 & 34,00 & 0,340 & 44,10 & 0,194 & 0,366 \\
\hline India & 74,30 & 0,620 & 64,00 & 0,640 & 62,00 & 0,743 & 0,647 \\
\hline India* & 89,00 & 0,764 & 59,00 & 0,590 & 76,4 & 0,890 & 0,727 \\
\hline Indonesia & 98,00 & 0,850 & 96,00 & 0,960 & 85,00 & 0,980 & 0,908 \\
\hline Kenya & 70,00 & 0,958 & 75,00 & 0,750 & 95,80 & 0,700 & 0,845 \\
\hline Malawi & 98,50 & 0,558 & 21,00 & 0,210 & 55,80 & 0,985 & 0,513 \\
\hline Malaysia & 95,00 & 0,960 & 88,00 & 0,880 & 96,00 & 0,950 & 0,931 \\
\hline Mexico & 97,90 & 0,974 & 94,00 & 0,940 & 97,40 & 0,979 & 0,963 \\
\hline Morocco & 80,00 & 0,705 & 79,00 & 0,790 & 70,50 & 0,860 & 0,758 \\
\hline Nigeria & 65,00 & 0,690 & 78,00 & 0,780 & 69,00 & 0,650 & 0,713 \\
\hline Pakistan & 59,00 & 0,614 & 70,00 & 0,700 & 61,40 & 0,590 & 0,638 \\
\hline Pakistan ${ }^{*}$ & 68,00 & 0,651 & 70,00 & 0,700 & 65,10 & 0,680 & 0,672 \\
\hline Peru & 93,80 & 0,883 & 75,00 & 0,750 & 88,30 & 0,938 & 0,847 \\
\hline Sri-Lanka & 98,00 & 0,920 & 92,00 & 0,920 & 92,00 & 0,980 & 0,930 \\
\hline Sri-Lanka* & 97,00 & 0,956 & 93,00 & 0,930 & 95,6 & 0,970 & 0,949 \\
\hline Tanzania & 58,00 & 0,780 & 55,00 & 0,550 & 78,00 & 0,580 & 0,670 \\
\hline Thailand & 88,00 & 0,988 & 94,00 & 0,940 & 98,80 & 0,880 & 0,954 \\
\hline Zambia & 72,50 & 0,766 & 84,00 & 0,840 & 76,60 & 0,725 & 0,788 \\
\hline Zimbabwe & 93,10 & 0,847 & 76,00 & 0,760 & 84,70 & 0,931 & 0,832 \\
\hline
\end{tabular}

Data Source: Self-elaboration based on indicators results from WB's and UNDP's database. *UNDP's database. ${ }^{* *}$ UNDP's database. ${ }^{* * *}$ WB's database

16

Manuel Antonio Jiménez Castillo

(c) (i) 8 (O)

Revista Economía y Sociedad by Universidad Nacional is licensed under a Creative Commons Reconocimiento-NoComercialCompartirlgual 4.0 Internacional License.

Creado a partir de la obra enhttp://www.revistas.una.ac.cr/index.php/economia 


\section{Table 2.}

\section{Health Outcomes}

\begin{tabular}{|c|c|c|c|c|c|c|c|}
\hline \multirow{3}{*}{ Countries } & \multicolumn{6}{|c|}{ Indicator $\backslash$ indexs } & \multirow{3}{*}{ Variable } \\
\hline & \multicolumn{2}{|c|}{ Infant Immunized rate } & \multicolumn{2}{|c|}{$\begin{array}{l}\text { Maternal Mortality rate } \\
\text { corrected }\end{array}$} & \multicolumn{2}{|c|}{$\begin{array}{l}\text { Population access to } \\
\text { safe water rate }\end{array}$} & \\
\hline & $\begin{array}{l}\text { Indicator } \\
(\%)^{*}\end{array}$ & Index & $\begin{array}{l}\text { Indicator } \\
\text { (x100.000 } \\
\text { births })^{* *}\end{array}$ & Index & $\begin{array}{l}\text { Indicator } \\
(\%)^{* * *}\end{array}$ & Index & \\
\hline Bangladesh & 49,00 & 0,490 & 600,00 & 0,444 & 46,00 & 0,460 & 0,471 \\
\hline Bangladesh $^{*}$ & 50,30 & 0,503 & 850,00 & 0,414 & 84,00 & 0,840 & 0,565 \\
\hline Bangladesh $^{* *}$ & 57,00 & 0,570 & 380,00 & 0,484 & 97,00 & 0,970 & 0,648 \\
\hline Bolivia & 48,00 & 0,480 & 420,00 & 0,475 & 83,00 & 0,830 & 0,566 \\
\hline Brazil & 56,60 & 0,566 & 160,00 & 0,559 & 76,00 & 0,760 & 0,612 \\
\hline Chile & 64,80 & 0,648 & 2300 & 0727 & 81,00 & 0,810 & 0,708 \\
\hline Ethiopia & 7,00 & 0,700 & $1.400,00$ & 0,370 & 45,00 & 0,450 & 0,555 \\
\hline Filipinas & 56,00 & 0,560 & 230,00 & 0,527 & 85,00 & 0,850 & 0,624 \\
\hline Ghana & 49,60 & 0,496 & 210,00 & 0,535 & 65,00 & 0,650 & 0,544 \\
\hline Haiti & 25,40 & 0,254 & $1.000,00$ & 0,400 & 26,00 & 0,260 & 0,292 \\
\hline India & 17,00 & 0,170 & 340,00 & 0,493 & 75,00 & 0,750 & 0,395 \\
\hline India ${ }^{*}$ & 21,00 & 0,210 & 540,00 & 0,453 & 84,00 & 0,840 & 0,428 \\
\hline Indonesia & 43,00 & 0,430 & 450,00 & 0,469 & 28,00 & 0,280 & 0,402 \\
\hline Kenya & 40,00 & 0,400 & $1.000,00$ & 0,400 & 57,00 & 0,570 & 0,442 \\
\hline Malawi & 65,40 & 0,654 & 560,00 & 0,450 & 19,00 & 0,190 & 0,487 \\
\hline Malaysia & 36,75 & 0,367 & 59,00 & 0,646 & 95,60 & 0,956 & 0,584 \\
\hline Mexico & 71,20 & 0,712 & 60,00 & 0,644 & 97,00 & 0,970 & 0,759 \\
\hline Morocco & 81,00 & 0,810 & 240,00 & 0,523 & 81,00 & 0,810 & 0,738 \\
\hline Nigeria & 5,00 & 0,050 & 700,00 & 0,431 & 57,00 & 0,570 & 0,275 \\
\hline Pakistan & 22,50 & 0,225 & 340,00 & 0,493 & 79,00 & 0,790 & 0,433 \\
\hline Pakistan ${ }^{*}$ & 23,00 & 0,230 & 320,00 & 0,498 & 91,00 & 0,910 & 0,467 \\
\hline Peru & 57,90 & 0,579 & 280,00 & 0,501 & 72,00 & 0,720 & 0,594 \\
\hline Sri-Lanka & 59,00 & 0,590 & 60,00 & 0,644 & 60,00 & 0,600 & 0,606 \\
\hline Sri-Lanka ${ }^{*}$ & 69,30 & 0,693 & 58,00 & 0,647 & 79,00 & 0,790 & 0,705 \\
\hline Tanzania & 53,00 & 0,530 & 530,00 & 0,455 & 54,00 & 0,540 & 0,513 \\
\hline Thailand & 92,00 & 0,920 & 44,00 & 0,671 & 84,00 & 0,840 & 0,837 \\
\hline Zambia & 63,90 & 0,639 & 940,00 & 0,405 & 17,00 & 0,170 & 0,463 \\
\hline Zimbabwe & 63,90 & 0,639 & 570,00 & 0,448 & 25,00 & 0,250 & 0,494 \\
\hline
\end{tabular}

Data Source: Self-elaboration based on indicators results from WB's and UNDP's database. *UNDP's database. **WB's database. ***UNDP's database. 
Table 3.

Food Security Outcomes

\begin{tabular}{|c|c|c|c|c|c|c|c|}
\hline \multirow{3}{*}{ Countries } & \multicolumn{6}{|c|}{ Indicator $\backslash$ indexs } & \multirow[b]{3}{*}{ Variable } \\
\hline & \multicolumn{2}{|c|}{$\begin{array}{l}\text { Infant with low weight } \\
\text { rate }\end{array}$} & \multicolumn{2}{|c|}{ Infant Mortality rate } & \multicolumn{2}{|c|}{$\begin{array}{l}\text { National Consumption } \\
\text { rate }\end{array}$} & \\
\hline & $\begin{array}{l}\text { Indicator } \\
(\%)^{*}\end{array}$ & Index & $\begin{array}{l}\text { Indicator } \\
(\%)^{* *}\end{array}$ & Index & $\begin{array}{l}\text { Indicator (per } \\
\text { thousand } \\
\text { births) }\end{array}$ & Index & \\
\hline Bangladesh & 7,80 & 0,685 & 50,00 & 0,500 & 186,00 & 0,243 & 0,434 \\
\hline Bangladesh $^{*}$ & 8,70 & 0,722 & 30,00 & 0,700 & 139,70 & 0,284 & 0,538 \\
\hline Bangladesh $^{* *}$ & 9,00 & 0,733 & 36,00 & 0,640 & 121,00 & 0,305 & 0,524 \\
\hline Bolivia & 4,00 & 0,462 & 9,00 & 0,910 & 105,00 & 0,326 & 0,586 \\
\hline Brazil & 2,50 & 0,305 & 8,00 & 0,920 & 160,00 & 0,265 & 0,535 \\
\hline Chile & 3,50 & 0,418 & 5,00 & 0,950 & 23,00 & 0,546 & 0,682 \\
\hline Ethiopia & 7,10 & 0,654 & 51,00 & 0,490 & 159,20 & 0,266 & 0,433 \\
\hline Filipinas & 5,40 & 0,562 & 20,00 & 0,800 & 66,00 & 0,393 & 0,589 \\
\hline Ghana & 8,40 & 0,710 & 8,00 & 0,920 & 210,00 & 0,225 & 0,600 \\
\hline Haiti & 2,00 & 0,239 & 28,00 & 0,720 & 163,50 & 0,262 & 0,439 \\
\hline India & 10,20 & 0,775 & 30,00 & 0,700 & 155,00 & 0,269 & 0,542 \\
\hline India* & 8,90 & 0.729 & 30,00 & 0,700 & 141,00 & 0,283 & 0,539 \\
\hline Indonesia & 10,6 & 0,788 & 14,00 & 0,860 & 109,00 & 0,320 & 0,629 \\
\hline Kenya & 5,60 & 0,575 & 11,00 & 0,890 & 149,00 & 0,275 & 0,581 \\
\hline Malawi & 5,00 & 0,537 & 49,00 & 0,510 & 253,0 & 0,198 & 0,390 \\
\hline Malaysia & 4,40 & 0,494 & 8,00 & 0,920 & 151,00 & 0,274 & 0,576 \\
\hline Mexico & 5,00 & 0,537 & 8,00 & 0,920 & 18,00 & 0,581 & 0,707 \\
\hline Morocco & 6,50 & 0,624 & 15,00 & 0,850 & 78,00 & 0,369 & 0,612 \\
\hline Nigeria & 4,40 & 0,494 & 16,00 & 0,840 & 133,00 & 0,292 & 0,551 \\
\hline Pakistan & 9,50 & 0,751 & 25,00 & 0,750 & 500,00 & 0,100 & 0,490 \\
\hline Pakistan* & 9,30 & 0,744 & 19,00 & 0,810 & 125,00 & 0,301 & 0,593 \\
\hline Peru & 4,40 & 0,494 & 10,00 & 0,900 & 92,60 & 0,344 & 0,596 \\
\hline Sri-Lanka & 6,65 & 0,632 & 28,00 & 0,720 & 156,00 & 0,268 & 0,521 \\
\hline Sri-Lanka* & 7,00 & 0,649 & 22,00 & 0,780 & 20,00 & 0,566 & 0,668 \\
\hline Tanzania & 6,80 & 0,639 & 14,00 & 0,860 & 160,00 & 0,265 & 0,577 \\
\hline Thailand & 6,10 & 0,603 & 9,00 & 0,910 & 17,00 & 0,589 & 0,720 \\
\hline Zambia & 3,30 & 0,398 & 59,00 & 0,410 & 191,70 & 0,239 & 0,339 \\
\hline Zimbabwe & 4,00 & 0,462 & 10,00 & 0,900 & 99,50 & 0,334 & 0,586 \\
\hline
\end{tabular}

Data Source: Self elaboration based on indicators results from WB's and UNDP's database. *UNDP's database. ${ }^{* *}$ WB's database. ${ }^{* * *}$ WB's database.

18 


\section{Table 4.}

Individual Income Microcredit Impact

\begin{tabular}{|c|c|c|c|c|c|c|}
\hline \multirow[b]{2}{*}{ Countries } & \multirow[b]{2}{*}{$\begin{array}{l}\text { Evaluation } \\
\text { program year }\end{array}$} & \multirow[b]{2}{*}{$\begin{array}{l}\text { Individual } \\
\text { Income } \\
\text { Microcredit } \\
\text { Impact in local } \\
\text { currency }^{*}\end{array}$} & \multirow[b]{2}{*}{$\begin{array}{c}\text { Exchange } \\
\text { Rate Local } \\
\text { Currency/\$ } \\
\text { PPP }\end{array}$} & \multirow[b]{2}{*}{$\begin{array}{l}\text { Individual } \\
\text { Income } \\
\text { Microcredit } \\
\text { Impact in } \\
\text { current } \\
\text { dollars, base } \\
\text { year }\end{array}$} & \multirow[b]{2}{*}{$\begin{array}{l}\text { Cumulative } \\
\text { Inflation } \\
\text { Rate }(\%)^{* *}\end{array}$} & \multirow{2}{*}{$\begin{array}{l}\text { Dependent } \\
\text { Variable } \\
\text { Individual } \\
\text { Income } \\
\text { Microcredit } \\
\text { Impact }\end{array}$} \\
\hline & & & & & & \\
\hline Bangladesh & 1986 & 69,21 & 0,380 & 26,30 & 79,63 & 47,26 \\
\hline Bangladesh $^{*}$ & 1997 & 83,30 & 0,200 & 16,66 & 34,0 & 22,33 \\
\hline Bangladesh $^{* *}$ & 2002 & $1.761,89$ & 0,037 & 65,19 & 22,67 & 79,98 \\
\hline Bolivia & 2008 & 195,10 & 0,503 & 98,14 & 4,25 & 102,32 \\
\hline Brazil & 2008 & 112,97 & 0,886 & 100,10 & 4,25 & 104,36 \\
\hline Chile & 2009 & 52,10 & 2,720 & 141,73 & 16,87 & 165,65 \\
\hline Ethiopia & 2006 & 51,98 & 0,443 & 23,03 & 9,63 & 25,25 \\
\hline Ghana & 2007 & 226,23 & 0,406 & 91,85 & 6,45 & 97,78 \\
\hline Haiti & 2003 & 20,19 & 0,103 & 2,08 & 20,15 & 2,5 \\
\hline India & 2003 & 245,66 & 0,053 & 13,02 & 20,15 & 15,65 \\
\hline India* & 2010 & 471,64 & 0,067 & 31,60 & 2,2 & 32,30 \\
\hline Indonesia & 1990 & $16.071,05$ & 0,0038 & 61,07 & 56,62 & 95,65 \\
\hline Kenya & 2003 & $1.968,35$ & 0,039 & 76,76 & 20,15 & 92,23 \\
\hline Malawi & 1995 & 9,49 & 0,263 & 2,94 & 39,12 & 4,1 \\
\hline Malaysia & 2010 & 142,13 & 0,734 & 104,33 & 2,20 & 106,63 \\
\hline Mexico & 2008 & $1.108,09$ & 0,126 & 139,62 & 4,25 & 145,56 \\
\hline Morocco & 2010 & 532,31 & 0,207 & 110,19 & 2,20 & 112,62 \\
\hline Nigeria & 2010 & 722,33 & 0,030 & 21,67 & 2,2 & 22,15 \\
\hline Pakistan & 2003 & 184,52 & 0,084 & 15,50 & 20,15 & 18,63 \\
\hline Pakistan ${ }^{*}$ & 2007 & $1.267,85$ & 0,056 & 71,00 & 6,45 & 75,58 \\
\hline Peru & 2000 & 148,00 & 0,577 & 85,40 & 27,50 & 108,89 \\
\hline Philippines & 2008 & $2.435,95$ & 0,042 & 102,31 & 4,25 & 106,66 \\
\hline Sri-Lanka & 2009 & $1.773,39$ & 0,056 & 99,31 & 2,91 & 102,2 \\
\hline Sri-Lanka* & 2005 & $2.449,77$ & 0,044 & 107,79 & 13,14 & 121,96 \\
\hline Tanzania & 2004 & $24.962,50$ & 0,0024 & 59,91 & 16,87 & 70,02 \\
\hline Thailand & 2008 & $1.794,69$ & 0,098 & 175,88 & 4,25 & 183,36 \\
\hline Zambia & 1999 & $20.350,56$ & 0,0016 & 32,56 & 30,30 & 42,43 \\
\hline Zimbabwe & 1998 & $1.201,16$ & 0,050 & 60,08 & 32,41 & 79,56 \\
\hline
\end{tabular}

Data Source: Self elaboration based on World Bank's database. * Outcomes derived from Impact assessment. To see data source go Bibliography 
Table 5.

Variable definitions

\begin{tabular}{|c|c|c|}
\hline Variable & Indicators & Description \\
\hline \multirow{3}{*}{ Education } & Population reaching grade 5 & $\begin{array}{l}\text { The estimated proportion of the population entering primary } \\
\text { school who reach grade } 5\end{array}$ \\
\hline & Youth literacy rate & $\begin{array}{l}\text { Population age } 15 \text { and above who can with understanding } \\
\text { read and write a short statement }\end{array}$ \\
\hline & Primary enrollment rate & $\begin{array}{l}\text { Total enrollment in primary education, regardless of age, } \\
\text { expressed as a percentage of the total population }\end{array}$ \\
\hline \multirow{3}{*}{ Health } & Infant Immunized rate & $\begin{array}{l}\text { The estimated proportion of the population under } 5 \text { who are } \\
\text { treated with anti-malaria anti-diarrhea and measles drugs }\end{array}$ \\
\hline & $\begin{array}{l}\text { Population access to safe } \\
\text { water rate }\end{array}$ & $\begin{array}{l}\text { The percentage of population using an improved drinking } \\
\text { water source }\end{array}$ \\
\hline & Maternal Mortality rate & $\begin{array}{l}\text { The number of maternal deaths per } 1,000 \text { women of } \\
\text { reproductive age in the population }\end{array}$ \\
\hline \multirow{3}{*}{ Food Security } & Infant Mortality rate & $\begin{array}{l}\text { The probability that a child born in a specific year will die } \\
\text { before reaching the age of one }\end{array}$ \\
\hline & National Consumption rate & $\begin{array}{l}\text { The share of a country's national consumption that accrues } \\
\text { to the poorest quintile of the population }\end{array}$ \\
\hline & Infant with low weight rate & A birth weight of a live born infant of less than $2.500 \mathrm{~g}$ \\
\hline $\begin{array}{l}\text { Microfinance } \\
\text { Impact }\end{array}$ & $\begin{array}{l}\text { Individual Income } \\
\text { Microfinance Impact }\end{array}$ & $\begin{array}{l}\text { The amount of income earned by a micro-borrower in } \\
\text { current dollars } 2011\end{array}$ \\
\hline
\end{tabular}

\section{Data Source: Self elaboration based on indicators results from WB's and UNDP's database}

20 
Economía y Sociedad, Vol. 20, № 48 Cierre al 31 de diciembre de 2015, pp. 1-21 EISSN: 2215-3403 URL http://www.revistas.una.ac.cr/economia

Table 6.

The Effects of Human Development Variables on Microcredit Impact

Dependent Variable: Microcredit Impact on Income

Included observations: 28

\begin{tabular}{lllll}
\hline \hline Variable & Coefficient & Std. Error & t-Statistic & Prob. \\
\hline \hline & & & & \\
Education & 108.99 & 25.47 & 4.27 & 0.0003 \\
Health & 156.95 & 29.14 & 5.38 & 0.0000 \\
Food Security & 146.38 & 52.21 & 2.80 & 0.0098 \\
C & -170.42 & 19.82 & -8.59 & 0.0000 \\
\hline \hline
\end{tabular}

\section{Table 7.}

The Effects of Human Development Variables on Poverty Reduction

Dependent Variable: Microcredit Impact on Poverty Reduction

Included observations: 18

\begin{tabular}{lllll}
\hline \hline Variable & Coefficient & Std. Error & t-Statistic & Prob. \\
\hline \hline & & & & \\
Education* & 91.18 & 26.37 & 3.45 & 0.0038 \\
Health* & 123.55 & 25.62 & 4.83 & 0.0003 \\
Food Security* & 187.58 & 56.91 & 3.29 & 0.0053 \\
C & -156.53 & 27.40 & -5.71 & 0.0001 \\
\hline \hline
\end{tabular}

